\title{
Correction to: Residential proximity to industrial combustion facilities and risk of non-Hodgkin lymphoma: a case-control study
}

Anjoeka Pronk ${ }^{1,2}$, John R. Nuckols ${ }^{3}$, Anneclaire J. De Roos ${ }^{4,5}$, Matthew Airola ${ }^{6}$, Joanne S. Colt ${ }^{1}$, James R. Cerhan" Lindsay Morton ${ }^{1}$, Wendy Cozen ${ }^{8}$, Richard Severson ${ }^{9}$, Aaron Blair ${ }^{1}$, David Cleverly ${ }^{10}$ and Mary H. Ward ${ }^{1,11^{*}}$

\section{Correction to: Environ Health 12, 20 (2013)}

https://doi.org/10.1186/1476-069X-12-20

Following publication of the original article [1], the authors reported an error in the unit of the average emission metric (AEI). The AEI was incorrectly reported as nanograms (ng) toxic equivalency quotient (TEQ)/year in the abstract, methods, discussion, and Table 1 . The correct unit is grams (g) TEQ/year. The authors apologize for this error.
Epidemiology Branch, Division of Cancer Epidemiology and Genetics, National Cancer Institute, 6120 Executive Blvd, EPS 8006, Bethesda, MD 20892, USA.

Published online: 01 November 2021

\section{Reference}

1. Pronk A, Nuckols JR, De Roos AJ, Airola M, Colt JS, Cerhan JR, et al. Residential exposure to industrial combustion facilities and risk of nonHodgkin lymphoma: a case-control study. Environ Health. 2013;12:20 PMC 3599890.

\begin{abstract}
Author details
'Division of Cancer Epidemiology and Genetics, National Cancer Institute, Department of Health and Human Services, Rockville, MD, USA. ${ }^{2}$ TNO, Zeist, The Netherlands. ${ }^{3}$ Department of Environmental and Radiological Health Sciences, Colorado State University, Fort Collins, CO, USA. ${ }^{4}$ Fred Hutchinson Cancer Research Center, Seattle, WA, USA. ${ }^{5}$ University of Washington Department of Epidemiology, Seattle, WA, USA. ${ }^{6}$ Westat, Inc., Rockville, MD, USA. ${ }^{7}$ Mayo Clinic College of Medicine, Rochester, MN, USA. ${ }^{8}$ Departments of Preventive Medicine, Pathology, and Norris Comprehensive Cancer Center, Keck School of Medicine, University of Southern California, Los Angeles, CA, USA. ${ }^{9}$ Department of Family Medicine and Karmanos Cancer Institute, Wayne State University, Detroit, MI, USA. ${ }^{10}$ National Center for Environmental Assessment, Office of Research and Development, United States Environmental Protection Agency (retired), Washington, DC, USA. ${ }^{11}$ Occupational and Environmental
\end{abstract}

The original article can be found online at https://doi.org/10.1186/1476-069X$12-20$.

\footnotetext{
${ }^{*}$ Correspondence: wardm@mail.nih.gov

${ }^{11}$ Occupational and Environmental Epidemiology Branch, Division of Cancer Epidemiology and Genetics, National Cancer Institute, 6120 Executive Blvd, EPS 8006, Bethesda, MD 20892, USA

Full list of author information is available at the end of the article
}

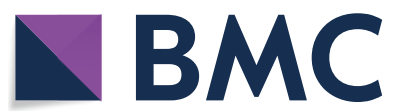

(c) The Author(s) 2021. Open Access This article is licensed under a Creative Commons Attribution 4.0 International License, which permits use, sharing, adaptation, distribution and reproduction in any medium or format, as long as you give appropriate credit to the original author(s) and the source, provide a link to the Creative Commons licence, and indicate if changes were made. The images or other third party material in this article are included in the article's Creative Commons licence, unless indicated otherwise in a credit line to the material. If material is not included in the article's Creative Commons licence and your intended use is not permitted by statutory regulation or exceeds the permitted use, you will need to obtain permission directly from the copyright holder. To view a copy of this licence, visit http://creativecommons.org/licenses/by/4.0/. The Creative Commons Public Domain Dedication waiver (http://creativeco mmons.org/publicdomain/zero/1.0/) applies to the data made available in this article, unless otherwise stated in a credit line to the data. 